\title{
ART EDUCATION IN MUSIC FIELD OF PUPILS WITH SPECIAL EDUCATIONAL NEEDS
}

\author{
Alica Vančová \\ Prof. PaedDr., CSc., Univerzita Komenského v Bratislave, \\ e-mail: vancova@fedu.uniba.sk,orcid.org/0000-0001-6885-4166,Slovakia \\ Margaréta Osvaldová \\ PaedDr., PhD., Univerzita Komenského v Bratislave, \\ e-mail: osvaldova@fedu.uniba.sk, Slovakia
}

\begin{abstract}
Music is particularly important for pupils with special educational needs because it plays an important compensatory and integration role in their lives. The orientation of education of pupils with special educational needs to various music-related disciplines opens up opportunities for their full professional application and the opportunity to integrate into society.

The aim of the study is to map the position of pupils with special educational needs at primary art schools. It analyzes individual disabilities in connection with music and art education, presents collected statistical data, data obtained by questionnaire form on a nationwide scale. It offers a more comprehensive view of the issue.
\end{abstract}

Keywords: primary art school, disabled students, music education.

DOI: http://dx.doi.org/10.23856/3707

\section{Súčasný stav}

Základná umelecká škola má na Slovensku ako výchovno-vzdelávacia inštitúcia svoju tradíciu a preto aj v odbornej literatúre sa jej venujú odborné štúdie. Takto zameraná literatúra rozoberá spravidla vyučovací proces a jednotlivé metodiky vyučovacích predmetov alebo sa viac zameriava na učitel'a či žiaka. V rámci prác zaoberajúcich sa konkrétnymi typmi žiakov na ZUŠ sa v nedávnej dobe objavili štúdie, ktoré boli upriamené na kategóriu žiakov so špeciálnymi edukačnými potrebami.

V rámci odbornej literatúry o umeleckom vzdelávaní sa mnohí autori zamerali predovšetkým na tie subkategórie žiakov so špeciálnymi edukačnými potrebami, s ktorými sa ako pedagógovia stretávali $v$ rámci hudobného vzdelávania najčastejšie a to najmä na vývinové poruchy učenia a poruchy správania. Avšak neevidujeme žiadnu štatistiku, ktorá by sa zaoberala žiakmi so špeciálnymi edukačnými potrebami na základných umeleckých školách (ZUŠ). Ministerstvo školstva Slovenskej republiky v spolupráci s Ústavom informácií a prognóz školstva uverejňuje na internete štatistiky obsahujúce počty integrovaných žiakov s konkrétnym zdravotným znevýhodnením v jednotlivých krajoch v súvislosti $\mathrm{s}$ ich umiestnením v štátnych, súkromných či cirkevných materských školách, základných školách, gymnáziách, konzervatóriách a stredných odborných školách, ako aj štatistiky týkajúce sa priamo špeciálnych materských a základných škôl a špeciálnych tried pri bežných základných školách podl'a postihnutia. Z týchto údajov nemožno určit' aké početné je zastúpenie žiakov so špeciálnymi edukačnými potrebami v základných umeleckých školách, jasne však indikujú, že výskyt takýchto žiakov je nutné predpokladat' (napr. iba fakt, že v kategórii individuálne integrovaných žiakov s uvedenými rôznymi postihnutiami figurujú študenti konzervatórií 
odkazuje na nutnost' ich príslušnej predchádzajúcej prípravy na nižšom stupni školy). Tak isto, ako nám v problematike žiakov so zdravotným postihnutím na základných umeleckých školách chýbajú základné štatistické údaje, chýba tu aj ucelenejšia teoretická báza, ktorá by učitel'om v rámci umeleckého vzdelávania poskytla metodický postup pri práci s takýmito žiakmi.

Vychádzajúc z absencie údajov vypovedajúcich o hudobnej edukácii žiakov so zdravotným postihnutím na slovenských základných umeleckých školách, bude mat' náš výskum v spolupráci s Budovou (2018) predovšetkým deskriptívny charakter, pričom bude sledovat' kvantitatívne ukazovatele.

\section{Výskumný problém a ciele výskumu}

Výskumným problémom našej práce je charakterizovanie stavu hudobného odboru žiakov so špeciálnymi edukačnými potrebami $\mathrm{v}$ prostredí slovenských základných umeleckých škôl a skúsenosti učitel’ov ZUŠ s vyučovaním týchto žiakov. Za hlavný ciel' nášho výskumu sme si stanovili získanie relevantných údajov vzhl'adom na náš výskumný problém. Konkrétne ciele, sledujúc kvantitatívne údaje, sme si určili nasledovne:

1. Priniest’ údaje o výskyte žiakov so zdravotným postihnutím na (jednotlivých) ZUŠ.

2. Zmapovat' študijné zamerania resp. predmety v rámci hudobného odboru, v ktorých sa žiaci so špeciálnymi edukačnými potrebami vzdelávajú.

3. Zistit' aké skúsenosti majú učitelia ZUŠ s vyučovaním so žiakmi so špeciálnymi edukačnými potrebami.

\section{Výskumné metódy a výskumné otázky}

$\mathrm{K}$ dosiahnutiu vytýčených ciel'ov sme sa rozhodli využit' kvantitatívne výskumné metódy, použili sme štatistické metódy a dotazník.

Śtatistické metódy nám najskôr slúžili k získaniu základných údajov, z ktorých sme pri príprave a organizácii výskumu vychádzali a neskôr sme pomocou nich spracovali výsledky nášho dotazníka.

Dotaznik, ako metóda efektívneho zberu informácií z viacerých zdrojov súčasne (určených výskumným súborom), nám poskytol odpovede na vytýčené výskumné otázky kvantitatívnej časti nášho výskumu.

Výskumné otázky sme s ohl’adom na skúmanie kvantitatívnych údajov rozdelili podl’a zamerania do dvoch skupín. Ako prvé uvádzame výskumné otázky vzt’ahujúce sa čisto na kvantitatívnu čast', teda na ich zodpovedanie sme použili štatistické spracovanie údajov z dotazníka:

- Aký typ zdravotného postihnutia je u žiakov na ZUŠ (v hudobnom odbore) najfrekventovanejší?

- Aké študijné zameranie si vyberajú žiaci so špeciálnymi edukačnými potrebami $\mathrm{v}$ rámci hudobného odboru?

- Dodržiavajú rodičia vždy povinnost' oboznámit' učitel'a s faktom, že ich diet’a má zdravotné postihnutie?

- Aká je priemerná dížka štúdia týchto žiakov v hudobnom odbore (Dlí̌ku štúdia tu chápeme vzhladom ku dížke študijného zamerania)?

- Majú učitelia záujem získavat' resp. dopĺnat' si vedomosti a informácie o konkrétnom zdravotnom postihnutí svojho žiaka vrátane špecifik práce s ním, a ak áno, akým spôsobom? 


\section{Výskumná vzorka}

Základom pre získanie prvotných údajov, z ktorých sme pri príprave a organizácii výskumu vychádzali boli štatistické metódy. Tieto údaje nám zároveň vymedzili aj náš výskumný súbor.

Zist'ovali sme presný počet všetkých základných umeleckých škôl na Slovensku, bez ohl'adu na ich zriad’ovatel'a, teda štátne, súkromné i cirkevné. Potom boli pre nás dôležité dva základné údaje. Prvým bol celkový počet žiakov, a druhým počet učitelov na ZUŠ v hudobnom odbore. Ako doplňujúci údaj sme si zvolili počet individuálne integrovaných žiakov so špeciálnymi edukačnými potrebami študujúcich na hudobne zameraných konzervatóriách (Vid’ poznámka pod čiarou č.2).

Všetky tieto informácie sme získali preštudovaním Štatistickej ročenky školstva (pre aktuálny školský rok), kde sme informácie najskôr vytriedili, potom sme nami vybrané údaje izolovali, vypísali až nakoniec sme ich spojili do vlastných tabuliek tak, aby čo najpresnejšie zodpovedali zameraniu našej práce a výskumu. Touto cestou sme dostali nasledovné údaje:

Tabul'ka 1

\section{Počet základných umeleckých škôl a konzervatórií v jednotlivých krajoch v školskom roku 2018/2019}

\begin{tabular}{|l|c|c|}
\hline & ZUŠ & konzervatóriá \\
\hline Banskobystrický kraj & 53 & 3 \\
\hline Bratislavský kraj & 43 & 4 \\
\hline Košický kraj & 45 & 4 \\
\hline Nitriansky kraj & 29 & 2 \\
\hline Prešovský kraj & 68 & 1 \\
\hline Trenčiansky kraj & 45 & 0 \\
\hline Trnavský kraj & 31 & 1 \\
\hline Žilinský kraj & 51 & 2 \\
\hline spolu na Slovensku & $\mathbf{3 6 5}$ & $\mathbf{1 7}$ \\
\hline
\end{tabular}

Z tabul'ky je možné vyčítat', že najviac základných umeleckých škôl sa nachádza v Prešovskom kraji a najmenej v Nitrianskom kraji. Najviac konzervatórí je v Bratislavskom a Košickom kraji, naopak najmenej, v Trenčianskom kraji, kde nie je k dispozícii žiadne konzervatórium.

Dáta obsiahnuté v uvedených tabul'kách majú len orientačný charakter aj napriek tomu, že takmer všetky informácie sú získané prostredníctvom Centra vedecko-technických informácií SR.

V prvej tabul'ke sme uviedli počty základných umeleckých škôl a konzervatórií v jednotlivých krajoch. Zistili sme, že celkový počet základných umeleckých škôl na Slovensku je 365 a počet konzervatórií je 17, avšak je potrebné si uvedomit', že nie všetky z uvedených škôl disponujú hudobným odborom, ide najmä o súkromné inštitúcie, ktorých je na Slovensku v školskom roku 2018/2019 presne 154 súkromných základných umeleckých škôl a 10 súkromných konzervatórií. 
Tabul'ka 2

Počet pedagógov hudobných odborov základných umeleckých škôl a počet pedagógov na konzervatóriách v jednotlivých krajoch v školskom roku 2018/2019

\begin{tabular}{|l|c|c|}
\hline & ZUŠ & konzervatórium \\
\hline Banskobystrický kraj & 363 & 137 \\
\hline Bratislavský kraj & 843 & 292 \\
\hline Košický kraj & 659 & 313 \\
\hline Nitriansky kraj & 459 & 119 \\
\hline Prešovský kraj & 911 & 56 \\
\hline Trenčiansky kraj & 595 & 0 \\
\hline Trnavský kraj & 432 & 23 \\
\hline Žilinský kraj & 875 & 103 \\
\hline spolu & $\mathbf{5 1 3 7}$ & $\mathbf{1 0 4 3}$ \\
\hline
\end{tabular}

V nasledujúcej tabul'ke sme uviedli počty pedagógov a žiakov v jednotlivých školách, avšak aj tu je potrebné podotknút', že niektorí pedagógovia, ale aj žiaci pôsobia na viacerých školách súčasne, $\mathrm{z}$ tohto dôvodu uvedené počty pokladáme za orientačné.

Vychádzajúc zo všetkých týchto údajov a po zvážení najefektívnejšieho riešenia realizácie empirickej časti našej práce sme stanovili výskumný súbor nasledovne:

Výskumný súbor pre získanie kvantitatívnych údajov prostredníctvom dotazníkovej metódy predstavujú pedagógovia hudobného odboru, ktorí pôsobia (pôsobili) na slovenských základných umeleckých školách. Vel'kost' tohto základného súboru je podl'a tabul'ky č.2 približne (maximálne) 5137 osôb.

\section{Organizácia a priebeh výskumu}

Skôr, ako sme pristúpili k vlastnej realizácii výskumu, bolo potrebné získat teoretické podklady a základné informácie potrebné k zostaveniu výskumného projektu. Ako prvé sme sa rozhodli spracovat' dostupné štatistické údaje a zároveň vytvorit' dotazník mapujúci základné fakty a súvislosti týkajúce sa našej problematiky. Vytvorený dotazník a jeho jednotlivé položky boli najskôr odkonzultované a následne otestované v predvýskume. Predvýskum sa realizoval nasledovne: vytvorený dotazník v printovej podobe bol osobne distribuovaný šiestim pedagógom hudobného odboru. Týchto šest' osôb bolo vybraných z radov pedagógov tak, aby boli zastúpene obe pohlavia rovnako, aby dížka ich pedagogickej praxe bola rôzna a aby prostredníctvom nich boli zastúpené tri rôzne základné umelecké školy. Dotazník bol vypĺn̆aný za prítomnosti výskumníka.

V samotnom výskume sme prostredníctvom e-mailu (e-mailové adresy na jednotlivé ZUŠ sme získali z portálu izus.sk a vyhl'adávaním mailového kontaktu na internetových stránkach jednotlivých škôl) distribuovali náš dotazník všetkým vedeniam základných umeleckých škôl na Slovensku s prosbou o vyplnenie a preposlanie/ šírenie dotazníka medzi svojich pedagógov hudobného odboru. Dotazník sme súbežne s tým opakovane uverejňovali aj na sociálnej sieti Facebook. Okrem toho sa náš dotazník šíril e-mailovou formou aj cez osobné adresy a objavil sa aj na internetovom portály izus.sk (Portál izus.sk je špecializovaný informačný systém pre základné umelecké školy. Jeho hlavnou funkciou je poskytovanie elektronickej administrácie dokumentov a komunikácie medzi školou, rodičmi a žiakmi). 


\section{Výsledky a vyhodnotenie údajov výskumu}

Do dotazníka, ktorým sme zbierali základné, orientačné údaje o problematike žiakov so zdravotným postihnutím na slovenských ZUŠ sa zapojilo celkovo 188 respondentov, z ktorých sme 3 dotazníky museli vylúčit' (Označený predmet ZUŠ v ktorom prebiehala výučba zdravotne postihnutého žiaka nezodpovedal hudobnému odboru, alebo respondent označil špecifické poruchy učenia ako mentálne postihnutie). Z celkovej návratnosti vyplnených dotazníkov tvorilo necelých $12 \%$ tých, ktoré boli vyplnené na základe šírenia prostredníctvom sociálnej siete Facebook a zvyšných $88 \%$ predstavovalo priamy odkaz na dotazník, v našom prípade na základe e-mailovej správy.

V evidovaných 185 odpovediach bolo zastúpených 91 rôznych ZUŠ, v dvoch prípadoch nebolo špecifikované o ktorú bratislavskú ZUŠ ide, v piatich prípadoch nebola uvedená konkrétna ZUŠ, v jednom prípade išlo dokonca o konzervatórium (Cirkevné konzervatórium $\mathrm{v}$ Bratislave) a v dvoch prípadoch išlo o respondentky, ktoré už aktuálne na ZUŠ nepôsobia (Jedna z nich žije momentálne v zahraničí, kde školská inštitúcia podobná našej ZUŠ neexistuje, a druhá je už na dôchodku). Šiesti respondenti uviedli v dotazníku súčasne dve pôsobiská. Ďalšie údaje vyplývajúce o ZUŠ ako početnost' odpovedí v rámci jednej školy a zastúpenie zapojených škôl podl’a krajov prikladáme v nasledovných tabul'kách.

Tabul'ka 3

\section{Početnost’ zastúpenia ZUŠ v rámci krajov s počtom vyplnených dotazníkov}

\begin{tabular}{|l|c|l|}
\hline \multicolumn{1}{|c|}{$\begin{array}{c}\text { Počty ZUŠ s hudobným } \\
\text { odborom }\end{array}$} & $\begin{array}{c}\text { celkom v } \\
\text { SR }\end{array}$ & zapojené do dotazníka + počet dotazníkov \\
\hline Bratislavský kraj & 35 & $13 / 41$ (+2dotazníky) \\
\hline Trnavský kraj & 25 & $5 / 6$ dotazníkov \\
\hline Trenčiansky kraj & 36 & $9 / 15$ dotazníkov \\
\hline Nitriansky kraj & 28 & $12 / 25$ dotazníkov \\
\hline Žilinský kraj & 45 & $13 / 22$ dotazníkov \\
\hline Banskobystrický kraj & 51 & $14 / 27$ dotazníkov \\
\hline Prešovský kraj & 55 & $11 / 16$ dotazníkov \\
\hline Košický kraj & 38 & $11 / 15$ dotazníkov \\
\hline
\end{tabular}

\section{Početnost' odpovedí na jednu ZUŠ}

\begin{tabular}{|r|l|}
\hline \multicolumn{2}{|c|}{ Počet odpovedí zo ZUŠ } \\
\hline 16 & 1 ZUŠ \\
\hline 9 & 1 ZUŠ \\
\hline 7 & 1 ZUŠ \\
\hline 6 & 2 ZUŠ \\
\hline 5 & 2 ZUŠ \\
\hline 4 & 5 ZUŠ \\
\hline 3 & 5 ZUŠ \\
\hline 2 & 13 ZUŠ \\
\hline 1 & 61 ZUŠ \\
\hline
\end{tabular}


Z týchto údajov je badatel'né, že najväčšiu návratnost' sme zaznamenali v Bratislavskom kraji. Výrazne k tomuto prispeli početnost'ou odpovedí predovšetkým dve bratislavské ZUŠ.

$\mathrm{V}$ odpovediach dotazníka bol pomer pohlavia respondentov zastúpený $\mathrm{v}$ úrovni (približne) zodpovedajúcej reálnemu pomeru učitel'ov a učiteliek na základných umeleckých školách v praxi. Taktiež sa ukázalo, že pomer jednotlivých pohlaví v súvislosti so skúsenost’ami (súčasnými alebo minulými) s vyučovaním zdravotne postihnutého žiaka sa zhoduje s pomerom v akom boli pohlavia respondentov zastúpené v celom dotazníku.

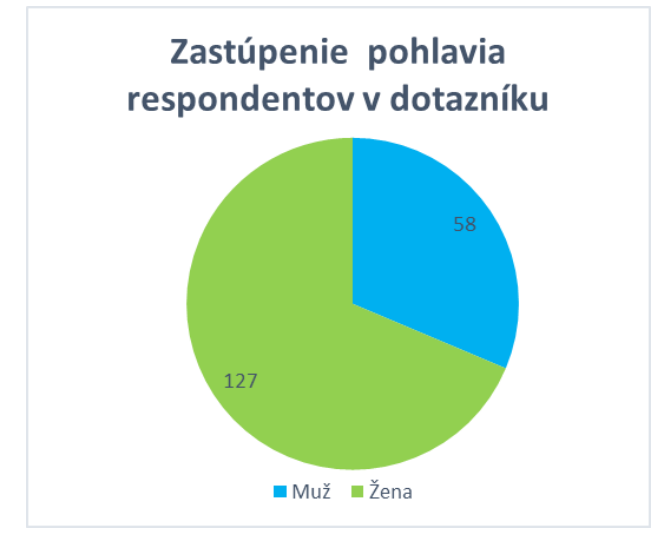

Graf 1. Zastúpenie pohlavia respondentov

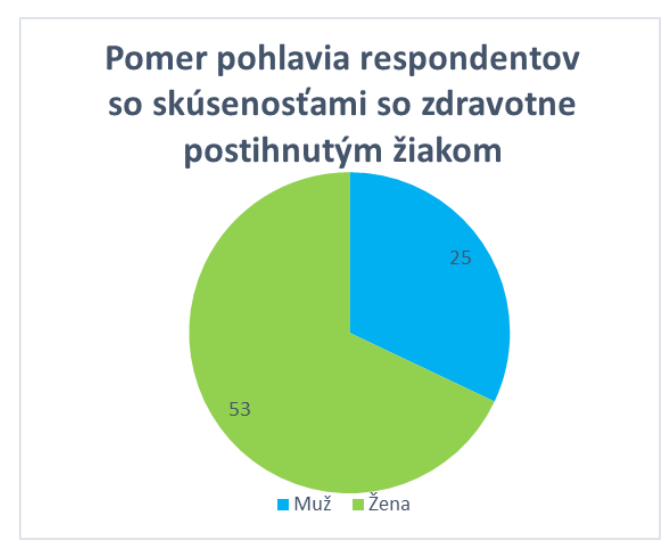

\section{Graf 2. Pomer pohlavia respondentov so skúsenost’ami so zdravotne postihnutým žiakom}

Posledným, povinným údajom, ktorý sa vzt’ahoval na osobu respondenta bola dížka jeho pedagogickej praxe. Ked’že medzi uvedenými odpoved’ami figurovali aj začínajúci učitelia s necelou ročnou praxou, ale aj učitel'ka už na dôchodku, bolo aj variačné rozpätie značne široké, približne 43 rokov. Zastúpenie respondentov podl’a dížky ich pedagogickej praxe sme pre lepšie priblíženie rozdelili do nasledovnej tabul'ky takto: 
Počet respondentov vzhl’adom na ich dížku pedagogickej praxe

Tabul'ka 5

\begin{tabular}{|l|c|}
\hline Dížka pedagogickej praxe & Počet respondentov \\
\hline 0 až 10 rokov & 80 \\
\hline 11 až 20 rokov & 33 \\
\hline 21 až 30 rokov & 41 \\
\hline 31 až 40 rokov & 28 \\
\hline viac ako 40 rokov & 3 \\
\hline
\end{tabular}

Klúčovou, a teda povinnou položkou v dotazníku bola otázka, či respondent má, mal alebo vôbec nemal vo svojej pedagogickej praxi skúsenost' so zdravotne postihnutým žiakom. Výsledky odpovedí respondentov predkladáme v tabul'ke 6 a ich percentuálne zloženie reprezentuje graf 3 .

Tabul'ka 6

\section{Skúsenosti učitel’ov ZUŠ so zdravotne postihnutým žiakom}

\begin{tabular}{|l|r|}
\hline \multicolumn{2}{|c|}{ Skúsenosti učitel'ov ZUŠ so zdravotne postihnutým žiakom } \\
\hline áno, mám takého žiaka (prípadne viac žiakov) & 35 \\
\hline áno mal(a) som, ale v súčasnosti takého žiaka nemám & 43 \\
\hline nie, nemal(a) som ani v súčasnosti nemám & 107 \\
\hline
\end{tabular}

Kombináciou faktorov dížky pedagogickej praxe a skúsenost’ami so zdravotne postihnutými žiakmi sme dostali údaje spracované v nasledujúcom kontingenčnom grafe.

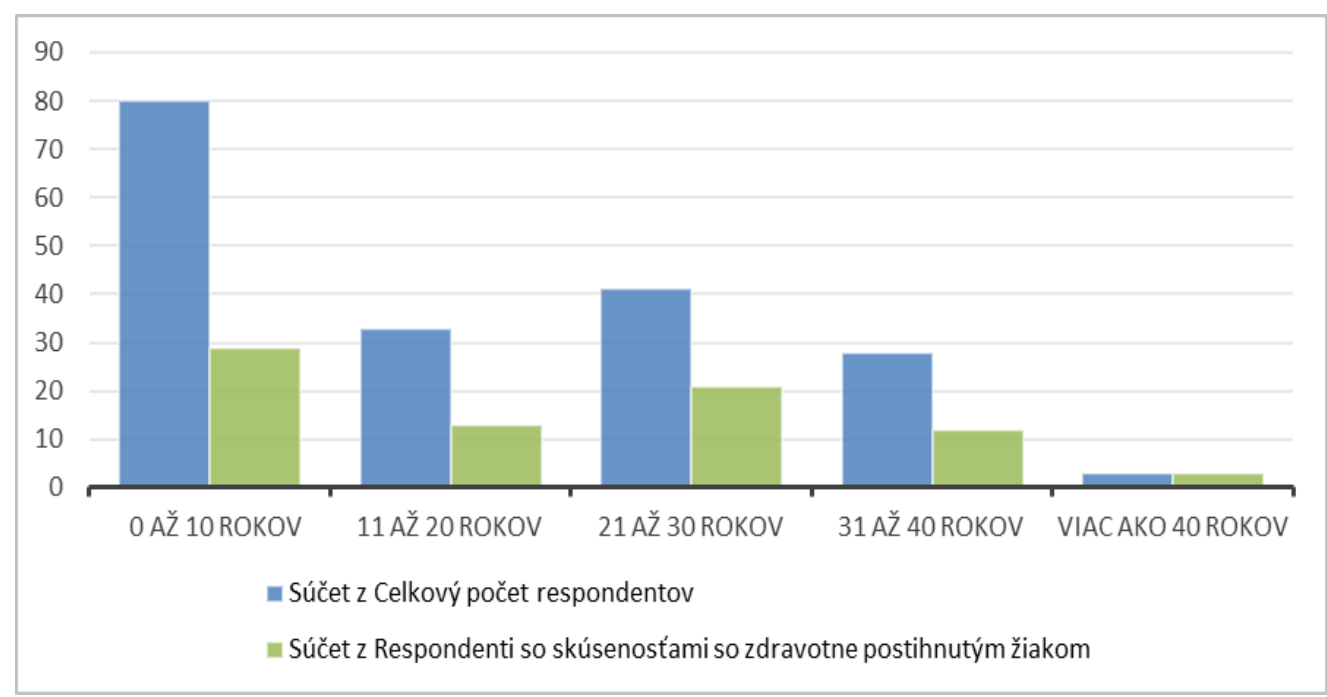

Graf 3. Porovnanie celkového počtu respondentov s počtom respondentov so skúsenost’ami so zdravotne postihnutým žiakom vzhl’adom k dížke pedagogickej praxe 
Z grafu 3 možno vyčítat', až 42 \% učitel'ov má, resp. malo vo svojej pedagogickej praxi žiaka so zdravotným postihnutím. Hoci možno predpokladat', že pri väčšej návratnosti dotazníka by sa podiel učitel'ov bez skúseností a učitel'ov so skúsenost'ami s takýmto žiakom mierne upravil v prospech tých, ktorí žiaka s postihnutím nemali, hodnotíme tieto výsledky za dostatočne výrazné na to, aby sa predmetnej problematike vodbornej literatúre venovala patričná pozornost'.

V prípade respondentov, ktorí uviedli, že doteraz nemali žiaka so zdravotným postihnutím alebo aktuálne nemajú nás zaujímal dôvod tejto skutočnosti. Táto položka v dotazníku už nebola povinná, čo sa odrazilo aj na značnom počte dotazníkov, spolu 42, v ktorých chýbala vyplnená táto odpoved'. Naopak, v jednom prípade bolo označených viac odpovedí súčasne (na základe viacerých žiakov). Zastúpenie jednotlivých odôvodnení približuje graf 4.

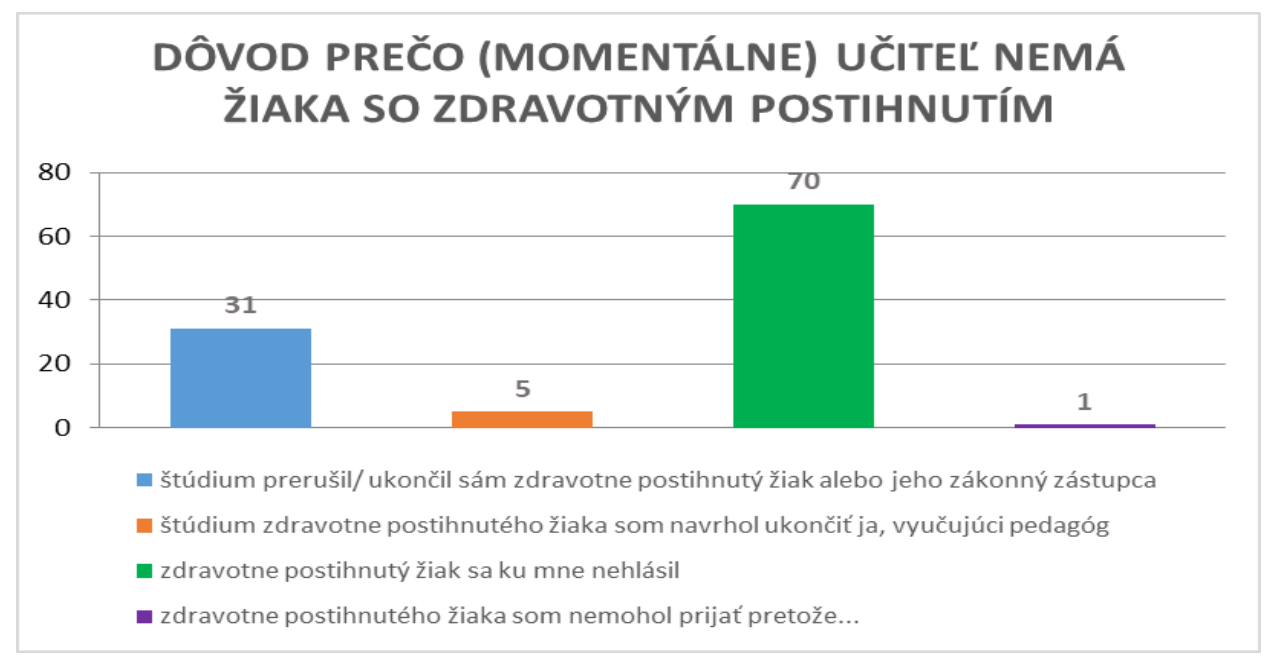

\section{Graf 4. Dôvod prečo (momentálne) učitel’ nemá žiaka so zdravotným postihnutím}

V dvoch prípadoch (z uvedených 42) neboli odpovede na túto položku zodpovedané priamo v otázke, no respondentky ich uviedli v poznámkach:

„Žiak momentálne študuje u inej kolegyne. Žial', musela som ho presunút' inam, nakol'ko bolo potrebné doplnit' či zredukovat' úväzky" (učitel'ka z Popradu).

„Nakol'ko som išla na materskú dovolenku, nemohla som sa svojej postihnutej žiačke viac venovat', pretože sme sa zároveň aj prest'ahovali“ (učitel'ka z Ilavy).

Respondentka, ktorá ako jediná označila, že žiaka nemohla prijat', konkretizovala svoju odpoved' nasledovne: „Nemal žiadne predpoklady na zvládnutie čo len minimum požadovaného, ale som ho učila 6 rokov súkromne. Teraz sa stretávame vel'mi sporadicky pre zopakovanie naučeného. U tohto žiaka išlo skôr o to, aby mal na každý deň program, pretože do školy už nemohol chodit' pre pokročilý vek. Samozrejme pri každej zafixovanej vedomosti mal žiak, rodič, ale aj ja, dobrý pocit z úspechu“. V tomto konkrétnom prípade išlo o žiaka s viacnásobným (TP + MP) postihnutím, pričom sa podl'a d'alších odpovedí respondentky používala $\mathrm{v}$ rámci hudobnej edukácie hra na zobcovej flaute jednou rukou (v rozsahu 5 tónov), hra na klavíri jedným prstom a spev. Respondentka tiež využila možnost' konzultácie s kolegami. 
Ďalšie údaje, ktoré sme dotazníkovou metódou zistili sa už viazali na aktuálne alebo minulé skúsenosti pedagógov ZUŠ s hudobnou edukáciou zdravotne postihnutých žiakov. Prvý konkretizujúci údaj, ktorý nás zaujímal, bol druh zdravotného postihnutia žiaka. Aj $\mathrm{v}$ tejto položke dotazníka bolo možné označit' viacero odpovedí ( $\mathrm{v}$ prípade viacerých žiakov), čo využilo 22 respondentov. Výsledky predkladáme v nasledujúcom grafe.

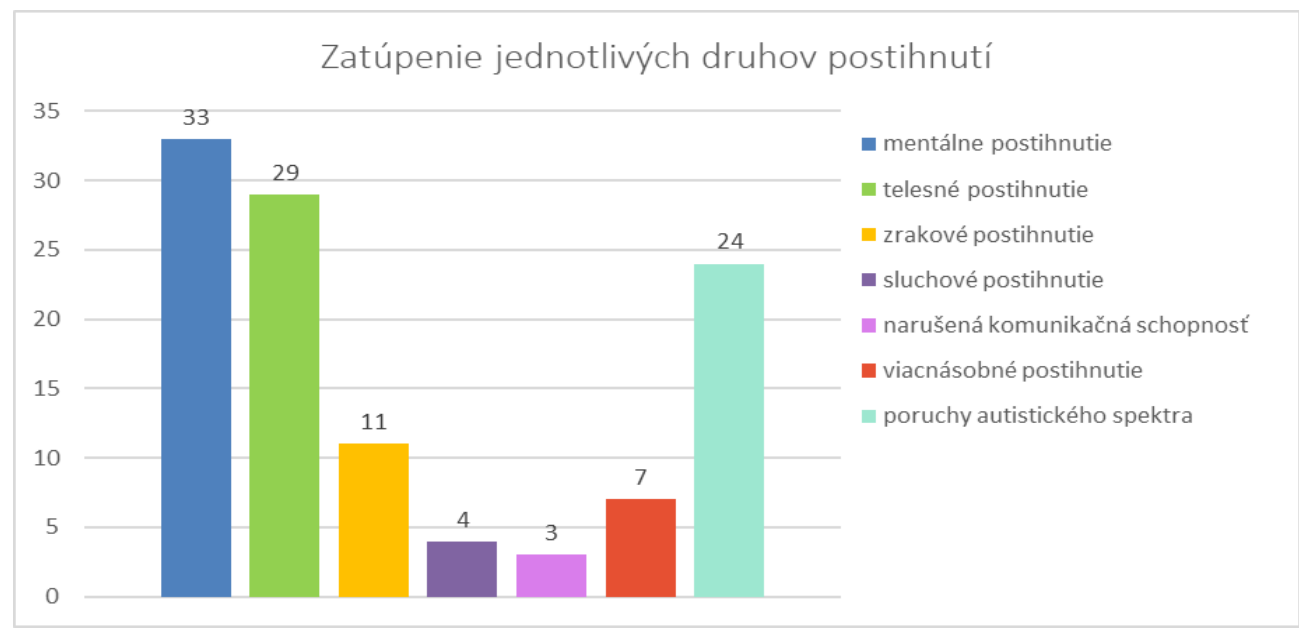

\section{Graf 5. Zastúpenie jednotlivých druhov postihnutí podl’a odpovedí z dotazníka}

Tieto výsledky jasne poukazujú na fakt, že i ked’ sa niektoré druhy postihnutí vyskytujú iba v malom množstve, nemožno automaticky vylúčit’ ani jeden z nich. Zároveň sa tu ukazuje, ktoré z jednotlivých postihnutí sú zastúpené najčastejšie.

Vychádzajúc z toho, že nie každé postihnutie musí byt' navonok viditel'né, zaujímalo nás, akým spôsobom sa učitelia o danom postihnutí svojho žiaka dozvedeli. Všímali sme si tu predovšetkým, či je povinnost' rodičov oboznámit' učitel’a s faktom, že ich diet’a má zdravotné postihnutie, dodržiavaná vždy alebo nie. Pre zodpovedanie položky sledujúcej túto oblast' mohli respondenti použit' jednu, ale i viac zo štyroch možností. Viac možností v rámci svojej odpovede využilo 26 respondentov. Výsledky pre túto oblast' sme zhrnuli do nasledujúceho grafu.

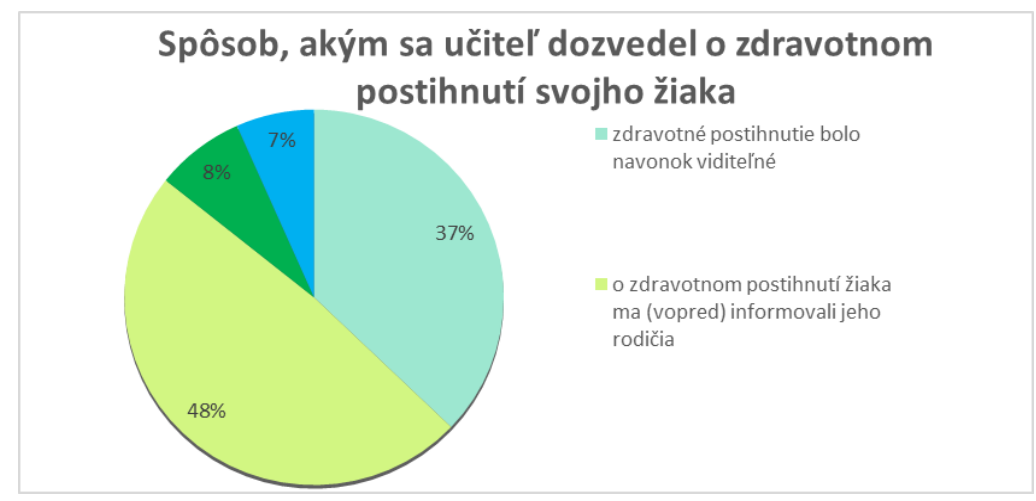

Graf 6. Spôsob, akým sa učitel’ dozvedel o zdravotnom postihnutí svojho žiaka 
Ako z odpovedí viditel'ných v grafe 6 vyplýva, isté percento učitel'ov doteraz nemá potvrdené zdravotné postihnutie svojho žiaka a približne rovnaká čast' učitel'ov sa o tomto fakte dozvedela až potom, čo konfrontovala rodičov. Viac o niektorých takýchto prípadoch sme sa dozvedeli z doplňujúcich informácií od respondentov.

Ďalším údajom, ktorý nás v súvislosti so zdravotne postihnutými žiakmi zaujímal, bolo, aké študijné zameranie v hudobnom odbore na ZUŠ navštevujú, resp. ktoré z nich je najfrekventovanejšie. Jednotlivé kategórie sme tu určili podla základného nástrojového delenia pričom sme nechali priestor pre doplnenie, v možnosti ,iné“, v prípade špeciálne vytvorených predmetov, alebo predmetov nezodpovedajúcich ponúknutým možnostiam. Respondenti, ktorí vybrali možnost' „iné“ vo svojich odpovediach uviedli: v dvoch prípadoch predmet hudobnej náuky, teda povinný predmet skupinového vyučovania, v jednom prípade išlo o spevácky zbor a v d’alších dvoch prípadoch išlo o špeciálne predmety. Tie nás z uvedených odpovedí zaujímali najviac. Jedným z nich je „integrovaný hudobný súbor“ a druhým „hudobná dielňa“. V prípade predmetu hudobná dielňa sme sa z dotazníka d'alej dozvedeli, že tento predmet funguje dva roky, z toho prvý rok ako oficiálny predmet -na ZUS̆ A. Cígera v Kežmarku, a navštevujú ho žiaci s Downovým syndrómom a Detskou mozgovou obrnou. Respondentka tu tiež uviedla, že: „Všetky deti navštevujúce Hudobnú dielňu (s prvkami muzikoterapie) majú aj individuálnu hodinu hry na klavíri. Účinkujú spoločne na triednych koncertoch so zdravými det'mi- čo pokladám za obrovský prínos pre všetkých... ". O predmete integrovaný hudobný súbor sme sa z dotazníka dozvedeli iba tol'ko, že sa uskutočňuje na ZUŠ J. Kowalského v Bratislave a navštevujú ho žiaci s poruchami autistického spektra, telesným a mentálnym postihnutím.

Sumárne výsledky našich dát z tejto položky v dotazníku znázorňuje graf 7 , ktorý sme zostavili na základe údajov (zo Štatistickej ročenky školstva) pojednávajúcich o celkovom zastúpení jednotlivých študijných odborov ZUŠ k aktuálnemu školskému roku.

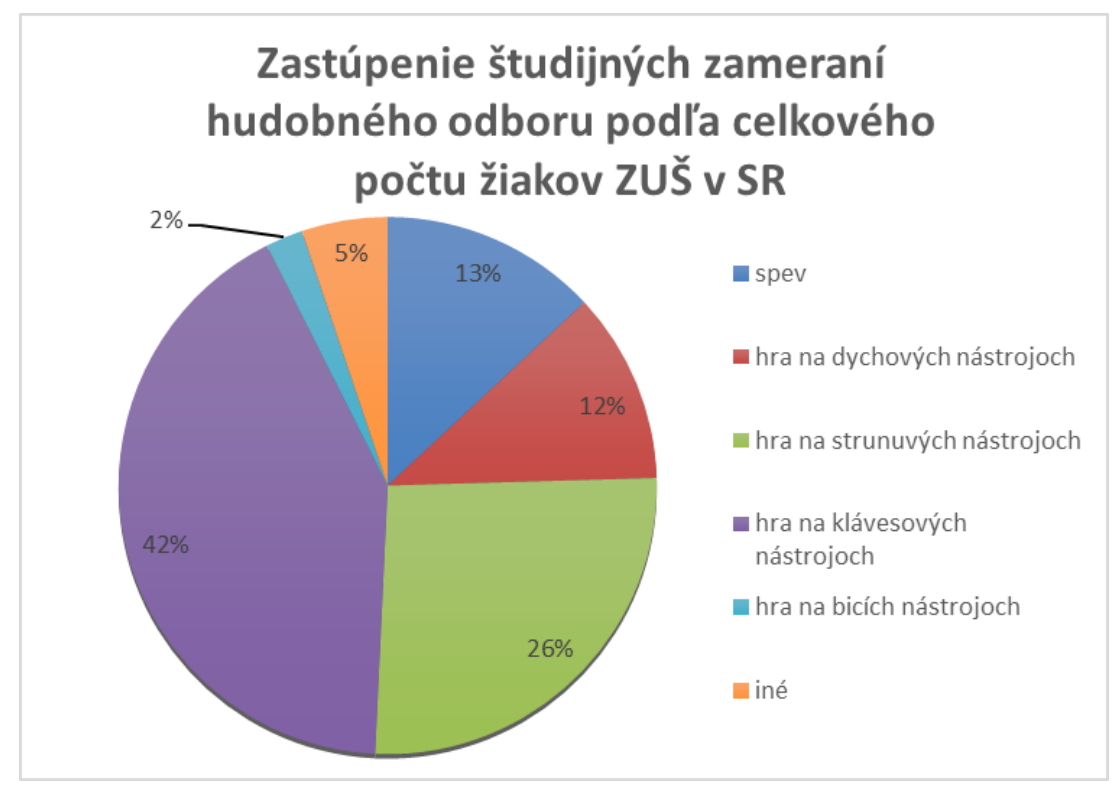

Graf 7. Zastúpenie študijných zameraní hudobného odboru podl’a celkového počtu žiakov ZUŠ v SR 
Z grafu 7 vyplýva, že najvýraznejší rozdiel medzi študijnými zameraniami volenými zdravotne postihnutými žiakmi je medzi dychovými a strunovými nástrojmi. Kým vo všeobecnosti predstavuje hra na strunových nástrojoch až štvrtinu z celkového zastúpenia a hra na dychových nástrojoch iba približne osminu, u jednotlivcov so zdravotným postihnutím je tento pomer opačný! Ostatné študijné zamerania sú približne rovnako zastúpené.

Okrem druhu zdravotného postihnutia a študijného zamerania sme u respondentov zist’ovali aj dížku štúdia žiaka. Získané údaje sa pritom delili v závislosti od toho či išlo o už ukončené štúdium alebo ešte prebiehajúce štúdium. Príslušné výsledky mapuje graf 8 a tabul'ka 7 .

\title{
DÍžka štúdia žiakov so zdravotným postihnutím na ZUŠ
}

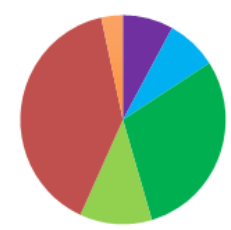

\author{
—štúdium prebiehalo celú dĺžku štúdijného zamerania \\ n štúdium prebiahalo menej ako rok \\ - štúdium prebiehalo 1 až 2 roky \\ घ štúdium prebiehalo 3 až 4 rokov \\ nštúdium stále prebieha \\ च z toho odpovede označujúce prebiehajúce aj ukončené štúdium (viac žiakov)
}

\section{Graf 8. Dížka štúdia žiakov so zdravotným postihnutím na ZUŠ}

Počet žiakov so zdravotným postihnutím vzhl’adom $\mathbf{k}$ ich dížke prebiehajúceho a už

Tabul'ka 7 ukončeného štúdia na ZUŠ

\begin{tabular}{|l|c|l|c|}
\hline Dížka štúdia zdravotne postihnutého žiaka & \multicolumn{1}{|c|}{$\begin{array}{c}\text { ukončené } \\
\text { na ZUŚ }\end{array}$} & $\begin{array}{l}\text { prebiehajúce } \\
\text { štúdium }\end{array}$ & spolu \\
\hline menej ako rok & 7 & 7 & 14 \\
\hline 1 až 2 roky & 26 & 10 & 36 \\
\hline 3 až 4 rokov & 10 & 12 & 22 \\
\hline celá dížka študijného zamerania & 7 & $4(+4+1+1+1)$ & 18 \\
\hline žiakov spolu & 50 & 40 & 90 \\
\hline
\end{tabular}

V prípade údajov uvedených $\mathrm{v}$ zátvorkách pri prebiehajúcom štúdiu ide o štúdium presahujúce 4 roky i štandardnú dížku študijného zamerania. Konkrétne o 5, 8, 10 a 11 rokov, uvedených v zátvorkách presne v tomto poradí. 
Poslednou otázkou nášho dotazníka pre respondenta, ktorý uviedol, že má alebo mal vo svojej pedagogickej praxi zdravotne postihnutého žiaka bolo, či využil nejakú formu poradenskej pomoci alebo doplnkového štúdia na to, aby sa o danom postihnutí žiaka, prípadne o možnostiach efektívnejšieho rozvoja jeho hudobných kompetencií dozvedel viac. $\mathrm{V}$ rámci tejto položky bolo $\mathrm{k}$ dispozícii na výber pät' rôznych odpovedí a označených mohlo byt' zároveň aj viac z nich. Možnost' označit' viac odpovedí súčasne využilo 32 respondentov, pričom počet súčasne označených odpovedí v jednom dotazníku bol dve, tri aj štyri.

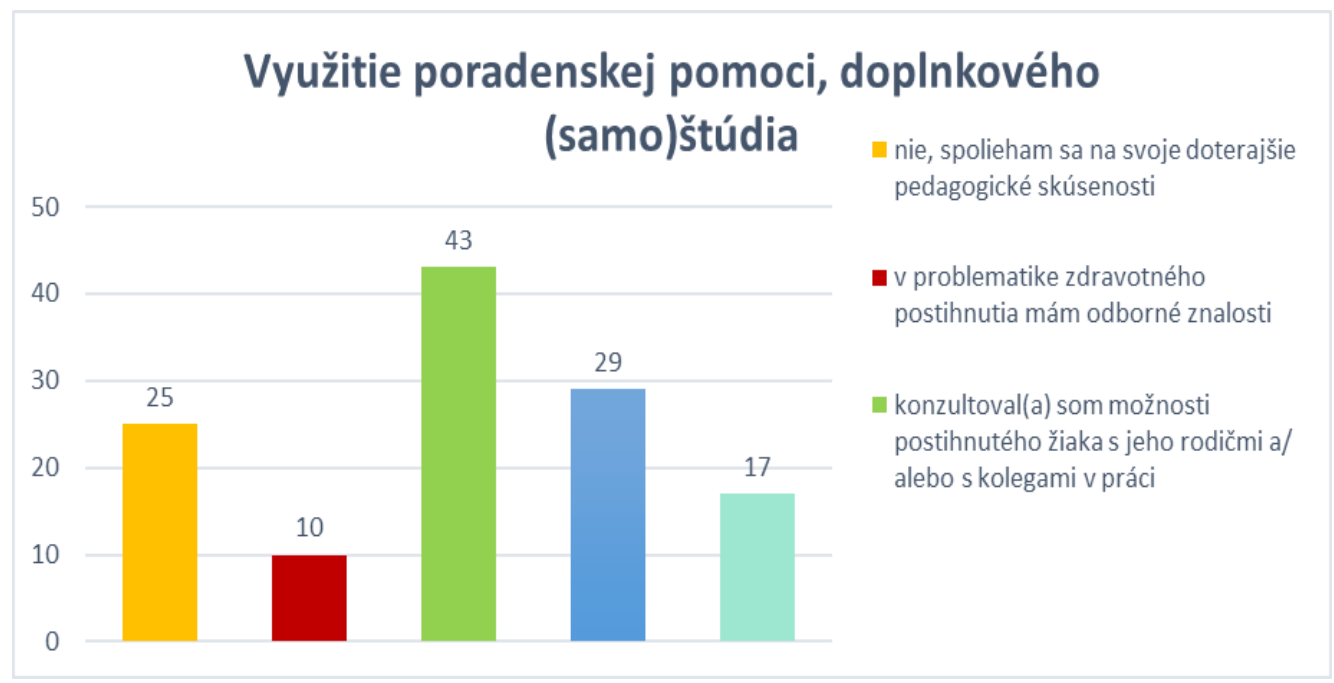

Graf 9. Využite poradenskej pomoci alebo doplnkového (samo)štúdia pre získanie informácií o zdravotnom postihnutí žiaka, resp. o možnostiach efektívnejšej práce s ním

Všetky údaje, ktoré sme dotazníkovou metódou zistili nad rámec našich otázok, pochádzajú od respondentov, ktorí sa rozhodli využit' priestor na konci dotazníka pre doplnenie a spresnenie svojich odpovedí, alebo pre akékol’vek pripomienky či vyjadrenie svojho názoru ( $\mathrm{k}$ dotazníku samotnému alebo $\mathrm{k}$ predmetnej problematike). V niekol'kých prípadoch bol tento vol'ný priestor využitý aj na vyjadrenie podpory našej práce či prosby o pomoc resp. o poskytnutie informácií, ktoré by pomohli konkrétnej respondentke pri práci s jej postihnutým žiakom. Taktiež sa tu prejavil aj priamy záujem o celkové výsledky nášho výskum.

\section{ZÁVER A DISKUSIA}

V rámci empirickej časti sa nám podarilo priniest’ odpovede na každú z vopred stanovených výskumných otázok. Zistili sme, že najčastejšie sa zo zdravotných postihnutí vyskytuje na ZUŠ u žiakov mentálne postihnutie, potom telesné postihnutie a poruchy autistického spektra. Všetky ostatné druhy postihnutí sú síce tiež zastúpené, no vo výrazne menšej miere. U týchto žiakov sme zaznamenali, že výber ich študijných zameraní v rámci hudobného odboru sa od celkového zastúpenia jednotlivých študijných zameraní (v celoslovenskom merítku) líši iba vopačnom pomere vol'by dychových a strunových nástrojov. Dychové nástroje si tu zdravotne postihnutí žiaci vyberajú podstatne častejšie. 
Samotná dížka štúdia týchto žiakov je ovplyvnená viacerými faktormi a je rovnako individuálna ako u bežnej populácie žiakov. Výsledky priniesli údaje aj o dížke už ukončeného štúdia, aj o prebiehajúcom štúdiu. Vo väčšine prípadov už ukončeného štúdia sme zaznamenali silnú prevahu trvania v rozmedzí jeden až dva roky, pri ešte prebiehajúcom štúdiu boli výsledky rovnomernejšie rozložené, pričom s malou prevahou tu bola zastúpená skupina s trvaním tri až štyri roky. Ukázalo sa tiež, že rodičia nedodržiavajú vždy svoju povinnost' informovat' učitel'ov ZUŠ (od začiatku) o skutočnosti, že ich diet'a má zdravotné postihnutie. Dôvodom sú obavy z odmietnutia. Hoci sa takýchto prípadov v našom výskume objavilo menej ako prípadov, kedy rodičia vopred informovali učitel'a, jasne to ale poukazuje na skutočnost', že učitelia na ZUŠ majú obavy pracovat' so žiakom sonšpeciálnymi edukačnými potrebami. Netýka sa to všetkých, čo dokazuje aj početná skupina učitelov ochotných dozvediet' sa viac o zdravotnom postihnutí žiaka, resp. o alternatívnych, iných postupoch a spôsoboch práce s ním, a tým skvalitňovat' ich spoločné hodiny. K tomuto je však potrebné otvorené jednanie rodiča s učitel’om, aby učitel' presne vedel, v čom spočíva t’ažisko problémov konkrétneho žiaka. Ako najčastejšie formy snahy o zlepšenie spoločných hodín so zdravotne postihnutým žiakom uvádzali učitelia práve konzultácie s rodičmi žiaka a s kolegami v práci, a tiež vyhl'adanie si informácií v odbornej literatúre či na internete. Možnost' využit' konzultáciu s odborníkom využilo iba málo respondentov. Vel'mi kladne hodnotíme fungovanie troch „špeciálnych“ predmetov, na ktorých sa zúčastňujú žiaci so špeciálnymi edukačnými potrebami a zároveň by sme tak chceli poukázat' na príklad a priestor, ktorý by mohli využit' aj ostatné ZUŠ, predovšetkým tie, ktoré už nejakí žiaci so špeciálnymi edukačnými potrebami navštevujú.

Skupina žiakov so špeciálnymi edukačnými potrebami tvorí na základných umeleckých školách menšinu, avšak jej prítomnost' nesmie zostávat' bez povšimnutia odbornej verejnosti. Práca s týmito žiakmi si v mnohých prípadoch vyžaduje špecifický prístup a má také špecifiká, na ktoré bežne hudobný pedagóg nie je školený. Preto je otázkou, čo by aktuálnu situáciu mohlo zlepšit' a dostat' viac do povedomia. Domnievame sa, že poskytnutie školení, prednášok alebo inej osvetovej činnosti na tému žiakov so špeciálnymi edukačnými potrebami, by výrazne pomohla prekonat' obavy či strach učitel'ov ZUŠ prijat' takéhoto žiaka do svojej triedy, a zároveň by v prípade tých, ktorí už vo svojej triede zdravotne postihnutého žiaka majú, zabezpečovala aspoň čiastočne aj podpornú funkciu. Forma, akou by sa to všetko realizovalo, tak aby to bolo zaujímavé (i finančne) aj pre učitel'ov, ktorí nikdy takýchto žiakov nemali, by mohla mat' napríklad aj podobu ponuky v kontinuálnom vzdelávaní. Samozrejme, možností by tu bolo viac, no v prvom rade je potrebné, aby sa táto problematika rozpracovávala podrobnejšie, a hlavne aby sa dočkala aj praktických riešení.

Našimi odporúčaniami pre prax teda sú:

- Dôsledné dodržiavanie povinnosti rodičov informovat' učitel'a ZUŠ o zdravotnom postihnutí svojho diet'at'a

- Zlepšenie vzájomnej komunikácie učitel'ov, ktorí vyučujú žiaka so špeciálnymi edukačnými potrebami

- Podporovanie vzdelávania žiakov so špeciálnymi edukačnými potrebami na ZUŠ formou prednášok, školení či kontinuálneho vzdelávania pre učitel’ov a prostredníctvom vytvárania špeciálnych predmetov pre nich (ak je to vzhl'adom $\mathrm{k}$ postihnutiu potrebné)

- Ďalšie, bližšie spracovanie danej problematiky. 


\section{References}

Budová, T. (2018). Hudobná edukácia žiakov so zdravotným postihnutím na základných umeleckých školách. [Diplomová práca]. Univerzita Komenského v Bratislave, Pedagogická fakulta. [in Slovak].

Harčaríková, T. (2011). Pedagogika Telesne postihnutých, chorých a zdravotne oslabenýchTeoretické základy. Bratislava: IRIS. [in Slovak].

Kastelová, A., Lopúchová, J., Schmidtová, M., Tarcsiová, D. (2013). Pedagogika zmyslovo postihnutých raného a predškolského veku. Bratislava: IRIS. [in Slovak].

Pedagogicko-organizačné pokyny na školský rok 2015/2016. (2015). Bratislava. [Electronic resource]. Retrieved from https://www.minedu.sk/pedagogicko-organizacne-pokyny-naskolsky-rok-20152016/. [in Slovak].

Štátny pedagogický ústav v Bratislave. (2008). Štátny vzdelávaci program pre základné umelecké školy (ISCED 2B-Nižšie sekundárne umelecké vzdelanie). ŠPÚ 2008. [Electronic resource]. Retrieved from http://www.statpedu.sk/sites/default/files/dokumenty/statnyvzdelavaci-program/nizsie_sekundarne_umelecke_vzdelanie_2b.pdf. [in Slovak].

Štátny pedagogický ústav v Bratislave. (2015). Povinné materiálno-technické a priestorové zabezpečenie výchovno-vzdelávacieho procesu v základnej umeleckej škole. [Samostatná príloha Štátneho vzdelávacieho programu pre základné umelecké školy]. [Electronic resource]. Retrieved from https://www.minedu.sk/data/att/7423.pdf, https://www.minedu.sk/data/att/8500.pdf. [in Slovak].

Štátny pedagogický ústav v Bratislave. (2015). Štátny vzdelávaci program pre základné umelecké školy. č.2015-6346/5841:1-10A0. [Electronic resource]. Retrieved from https://www.minedu.sk/inovovany-svp-pre-zakladne-umelecke-skoly-2-dodatok/:

https://www.minedu.sk/data/att/7409.pdf, $\quad$ https://www.minedu.sk/data/att/8501.pdf. [in Slovak].

Štátny pedagogický ústav v Bratislave. (2015). Vzdelávacie štandardy pre jednotlivé umelecké odbory ZUŚ. [Samostatná príloha Štátneho vzdelávacieho programu pre základné umelecké školy]. [Electronic resource]. Retrieved from https://www.minedu.sk/data/att/7422.pdf. [in Slovak].

Štátny pedagogický ústav v Bratislave. (2016). Rámcové učebné plány Štátneho vzdelávacieho programu základnej umeleckej školy. [Samostatná príloha Štátneho vzdelávacieho programu pre základné umelecké školy]. [Electronic resource]. Retrieved from https://www.minedu.sk/data/att/7421.pdf, $\quad$ https://www.minedu.sk/data/att/9377.pdf, https://www.minedu.sk/data/att/8499.pdf. [in Slovak].

Vančová, A. (2005). Základy pedagogiky mentálne postihnutých. Bratislava: Sapientia. [in Slovak].

Vančová, A. a kolektív. (2010). Edukácia mentálne postihnutých, špeciálne metodiky predmetov špeciálnej základnej školy. Bratislava: Iris. [in Slovak].

Zákon č. 245/2008 Z. z. , Zákon o výchove a vzdelávani (školský zákon) a o zmene a doplnení niektorých zákonov. [Electronic resource]. Retrieved from http://www.zakonypreludi.sk/zz/2008-245. [in Slovak].

Zákon č. 317/2009 Z. z. , Zákon o pedagogických zamestnancoch a odborných zamestnancoch a o zmene a doplneni niektorých zákonov. [Electronic resource]. Retrieved from http://www.zakonypreludi.sk/zz/2009-317. [in Slovak]. 